Article

\title{
Carrots (Daucus carota L.) Biofortified with Iodine and Selenium as a Raw Material for the Production of Juice with Additional Nutritional Functions
}

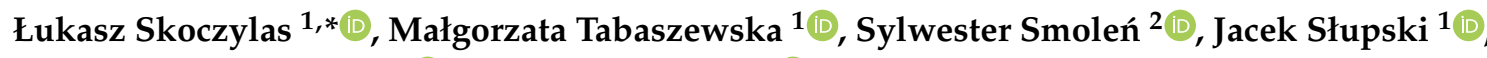 \\ Marta Liszka-Skoczylas ${ }^{3}$ (D) and Rafał Barański ${ }^{2}$ (D) \\ 1 Department of Plant Product Technology and Nutrition Hygiene, Faculty of Food Technology, \\ University of Agriculture in Krakow, Balicka 122 Str., 30-149 Krakow, Poland; \\ malgorzata.tabaszewska@urk.edu.pl (M.T.); jacek.slupski@urk.edu.pl (J.S.) \\ 2 Department of Plant Biology and Biotechnology, Faculty of Biotechnolgy and Horticulture, \\ University of Agriculture in Krakow, Al. 29 Listopada 54, 31-425 Krakow, Poland; \\ sylwester.smolen@urk.edu.pl (S.S.); rafal.baranski@urk.edu.pl (R.B.) \\ 3 Department of Engineering and Machinery for Food Industry, Faculty of Food Technology, \\ University of Agriculture in Krakow, Balicka 122 Str., 30-149 Krakow, Poland; \\ marta.liszka-skoczylas@urk.edu.pl \\ * Correspondence: lukasz.skoczylas@urk.edu.pl; Tel.: +48-12-662-47-64
}

Received: 20 August 2020; Accepted: 7 September 2020; Published: 10 September 2020 updates

\begin{abstract}
Many people around the world struggle with the problem of an insufficient supply of iodine (I) and selenium (SE) in their diet. Food enriched with these elements is a good source of iodine and selenium. Juices made from four carrot (CJ) cultivars and biofortified with iodine and selenium (BCJs) were investigated to determine their I and Se contents, their impact on the supply of these elements to the diet, and losses in the production process. Other juice parameters important for consumers health were also determined. A significant increase in I and Se content relative to CJ was observed for each BCJ. The losses of I and Se (relative to raw material) during juice preparation were depended based on variety and added elements. Carrot biofertilization with iodine and selenium contributed to decreased contents of dry matter, total soluble solids, protein, sugars, and $\beta$-carotene in the juices and lower antioxidative activity as compared with CJ. Biofortification had little effect on the color and $\mathrm{pH}$ of juices. Finally, six polyphenolic compounds were identified and determined. Despite the reduction in the content of some ingredients in $\mathrm{BCJ}$, they still remain their valuable source. Their added value is the increased content of iodine and selenium, which largely cover the daily demand for these elementals.
\end{abstract}

Keywords: biofortification; iodine; selenium; carrot juice

\section{Introduction}

Over the past few years, there has been a change in the perception of nutrition. In the past, food was treated only as an essential source of energy for the body. Currently, it also provides physiological benefits in the form of proper functioning of the body. A proper diet prevents the occurrence of many diseases, alleviates their course, and is of great importance during the recovery period. Guarantee of human well-being requires a balanced intake of nutrients.

Worldwide, many populations struggle with problems posed by deficits of elements indispensable for health and life maintenance, including, for example, iodine and selenium. In a human body, selenium enables transformation of thyroxine (T4) into tyrosine (T3) [1], prevents the outcomes of oxidative stress, takes part in the immune response of the body and testosterone synthesis, 
as well as prevents the development of cardiovascular diseases, viral infections, certain types of cancer, and type II diabetes. Selenium occurs naturally in Earth's crust, however its abundance therein varies [2]. Selenium occurs also in the animal kingdom, mainly in the form of selenocysteine, selenoneine (2-selenyl- $\mathrm{N}_{\alpha}, \mathrm{N}_{\alpha}, \mathrm{N}_{\alpha}$-trimethyl-L-histidine), as well as in the plant kingdom, in the form of selenomethionine, Se-methylselenocysteine, and $\gamma$-glutamyl-Se-methylselenocysteine. In both, the plant- and animal-based products, it can be found in the form of sodium selenite and selenate [3].

Iodine is another element whose deficiency is observed in the global population, leading to serious adverse effects in the human body. This element plays a key role in the proper functioning of the thyroid gland; iodine is a component of the hormones thyroxine (T4) and triiodothyronine (T3), produced by this gland. Iodine deficiency leads to many disorders in the body, including thyroid dysfunction (increased risk of cancer and goiter formation) and abnormal development of the neural tube and the brain in the prenatal and infancy period, which may manifest in cretinism [4,5]. The outcomes and the extent of its deficiency have afflicted entire populations and, for this reason, such international organizations, such as WHO, UNICEF, and ICCIDD, have joined their forces to cooperate with individual countries in the framework of national policies aimed to prevent it's deficiencies [6]. The recommended daily intake of iodine ranges from $150 \mu \mathrm{g}$ for adolescents to $260 \mu \mathrm{g}$ for breast-feeding women. Population groups that are at the highest risk of iodine deficiency include infants and small children, as well as pregnant and breast-feeding women $[7,8]$.

One of the popular methods to increase the supply of macro- and microelements to the body involves the enrichment of the most frequently consumed food products with these elements. However, this method leads to food enrichment with the mineral forms of elements, whereas biofortification of plants enables the synthesis of organic compounds of individual elements in their tissues [9]. Many of these compounds exhibit biological effects on a human body, which cannot be assured by the mineral forms of elements introduced directly into food products. In addition, they can be better absorbed and accumulated in tissues $[10,11]$.

A high number of investigations have been undertaken in the last decade that were aimed at plant biofortification with elements being most deficient in diets of millions of people worldwide [12]. These elements are provided to plants through soil fertilization or through foliar application. Research addressing simultaneous plant fertilization with iodine and selenium are scarce [13-15]. Even more sparse are reports on the losses of elements the plant materials had been enriched with and on the comparison of the quality of food products made of biofortified and non-biofortified raw materials. The available works usually concern the effect of cooking on the physicochemical parameters and composition of heat-treated vegetables $[16,17]$. Some authors have addressed the issue of preparing ready-to-eat meals made of plant materials biofortified with selected microelements [18], whereas sparse studies have been conducted to investigate the feasibility of using biofortified raw materials in standard technological processes and to evaluate the quality of the finished products. Food products manufactured under controlled conditions of technological processes can be easily standardized, subjected to quality control, and by this means become nutritious dietary supplements with additional and specified nutritive and health-promoting values. However, it is necessary to determine the loss of ingredients, in which the raw material was enriched, during the technological process in order to be able to estimate both the minimum and maximum raw material requirements. Too low or too high content of additionally introduced ingredients in the raw material can result in the final product not having the expected additional nutritional functions or containing higher doses than recommended.

Carrot (Daucus carota L.), due to high consumption in raw and processed form (especially juices) all over the world, can be a good carrier of microelements in the human diet. In addition, this valuable vegetable contains, i.a., carbohydrates $(10.6 \%)$, dietary fiber $(1.2 \%)$, proteins $(0.9 \%)$, fats $(0.2 \%)$, and minerals $(1.1 \%)$ including mainly calcium, iron, and phosphorus [19]. Furthermore, carrot, especially its orange-colored cultivars, is a fine source of carotenoids, including $\beta$-carotene, and many bioactive compounds, such as polyphenols including, in particular, such flavonoids as 
luteolin, quercetin, and kaempferol. In addition, it is a rich source of derivatives of cinnamic, chlorogenic, p-hydroxybenzoic, and caffeic acids [20].

The research hypothesis stated that juices obtained from raw materials biofortified with iodine and selenium are able to be used as valuable human dietary supplements with a high cover of \%RDA of these minerals as an additional nutritional function.

The objective of this study was to evaluate the effect of biofortification of four carrot cultivars with iodine and selenium on the physicochemical parameters and contents of selected bioactive compounds in thermally preserved carrot juices. The mineral composition of juices, (except for concentrations of iodine and selenium) have been addressed in a separate manuscript.

\section{Materials and Methods}

The experimental material included juices made of four cultivars of carrot, including three with the orange color (Aksona $F_{1}, S a m b a F_{1}$, and Kazan $F_{1}$ ) and one with the white color (White Satin) of the tuberous root. The subject of the study were juices made from all the aforementioned carrot cultivars biofortified with iodine and selenium via single pre-sowing fertilization of soil with iodine and selenium compounds in the following doses: $4 \mathrm{~kg} \mathrm{I} \cdot \mathrm{ha}^{-1}$ and $0.25 \mathrm{~kg} \mathrm{Se} \cdot \mathrm{ha}^{-1}$ in the form of KI and $\mathrm{Na}_{2} \mathrm{SeO}_{4}$. Juices pressed from carrot not fertilized with iodine and selenium served as the control. Raw

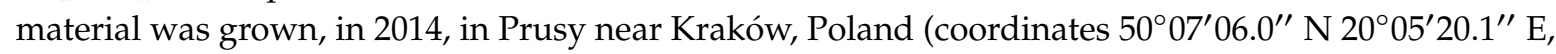
$376 \mathrm{~m}$ a.s.l.) under field conditions in four randomly selected plots. Carrot seeds were sown at the end of April, and tuberous roots were harvested at the end of September, at the harvest maturity stage. Carrot was cultivated in a heavy soil with a silty clay loam texture. Details of the field experiment (the physicochemical properties of the soil, the cultivation details, and weather conditions) were provided in our previous article [21]. The collected roots of control and biofortified carrot were washed in tap water and intended for juice preparation. Juices were made of all cultivars, according to the same procedure (Figure 1). After washing, peeling, and cutting into $1 \mathrm{~cm}$ pieces, carrots were blanched $\left(90^{\circ} \mathrm{C}, 3 \mathrm{~min}\right)$, and then juice was pressed using a juice extractor and a basket press. Juice obtained was poured into glass bottles and sterilized $\left(120^{\circ} \mathrm{C}, 20 \mathrm{~min}\right)$. After cooling, it was stored at a temperature of $4{ }^{\circ} \mathrm{C}$, for 3 months.

The content of I and Se in carrot juice samples was analyzed using an ICP-OES spectrometer (Prodigy, Leeman Labs, New Hampshire, MA, USA) after tetramethylammonium hydroxide (TMAH, Sigma-Aldrich Co. LLC, St. Louis, MO, USA) extraction according to Polish Standard and European Standard procedures [22,23].

Dry matter content of the carrot juices was determined following the gravimetric method according to [24], using a laboratory dryer (Pol-Eko-Aparatura SP. J., Wodzisław Ślaski, Poland).

Active acidity of the carrot juices was measured according to [25] using a pH meter (Metrohm, Herisau, Switzerland).

Total soluble solid (TSS) content of the carrot juices was determined with the refractometric method [24], using a Pal 3 refractometer (Atago, Tokyo, Japan). Extract content was read out from the saccharide scale based on the light refraction index of the solution analyzed. Temperature compensation for refractometry was determined.

Total protein content of the carrot juices was determined using the Kjeldahl method [25]. Samples were wet mineralized in sulfuric(VI) acid in a Büchi Digestion Unit K-424 (Büchi Labortechnik AG, Flawil, Switzerland) and distilled with water vapor in a Büchi Distillation Unit B-324 (Büchi Labortechnik AG, Flawil, Switzerland). The ammonia distillate obtained was titrated with $0.1 \mathrm{~mol} \cdot \mathrm{dm}^{-3} \mathrm{HCl}$.

Ethanolic extracts for analyses of contents of total sugar and total polyphenols, and for assays of the antioxidative activity against ABTS and DPPH radicals were prepared by weighing portions of juices and pouring them with $80 \%$ ethanol, followed by heating in a reflux condenser for $30 \mathrm{~min}$. After cooling, the juice samples were filtered. The prepared extract was used for analyses by the spectrophotometric method using a Hitachi U-2900 UV-Vis spectrophotometer (Hitachi, Tokyo, Japan). 


\begin{tabular}{|c|} 
Washing \\
In cold running water for $5 \mathrm{~min}$. \\
Hand peeling with a sterile vegetable peeler. \\
In cold running water for $2 \mathrm{~min}$. \\
\hline
\end{tabular}

\section{Cutting}

Cutting carrots with a sterile knife into pieces $1 \mathrm{~cm}$ thick.

\section{Blanching}

In hot water at $90 \pm 2^{\circ} \mathrm{C}$ for 3 min (carrot:water; $1: 5$ ).

\section{Cooling}

In water to ambient temperature.

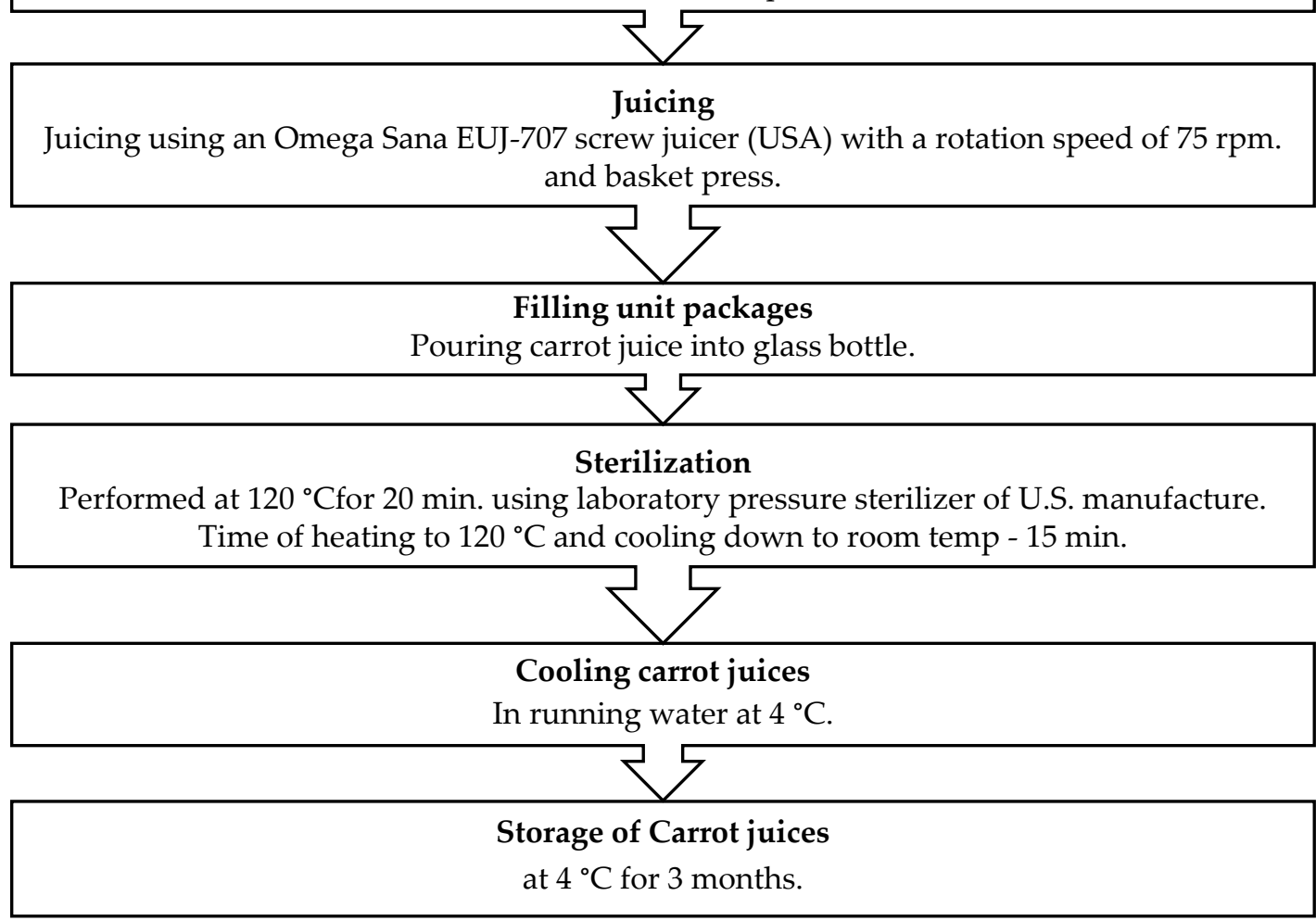

Figure 1. Scheme of production of carrot juice.

Total sugar content was determined by the method based on the color reaction of these compounds with anthrone [26]. The alcoholic extracts were appropriately diluted with distilled water. Next, $2 \mathrm{~mL}$ of anthrone were added to $1 \mathrm{~mL}$ of a diluted sample. The prepared samples were mixed and heated in a boiling water batch for $10 \mathrm{~min}$, and afterwards cooled. Furfural formed from pentoses and 5-hydroxy-methylfurfural formed from hexoses produce a color solution with anthrone; the intensity of its color is proportional to the sugar concentration in the extract. Color intensity measurement was carried out at a wavelength of $\lambda=625 \mathrm{~nm}$. 
The total polyphenols content was determined by the method involving the use of Folin-Ciocalteau reagent [27]. The reagent and $25 \%$ sodium carbonate were added to the samples, which were, then, mixed using a Labnet vortex mixer (Edison, NJ, USA). The mixed samples were left in a dark place, at room temperature, for $60 \mathrm{~min}$. Afterwards, absorbance was measured at a wavelength of $675 \mathrm{~nm}$. The total content of polyphenols was read out from a standard curve plotted for (+)-catechin.

The anti-free-radical activity of carrot juices was determined using a free DPPH radical (1,1-diphenyl-2-picrylhydrazyl) [28] and ABTS radical (2,2' -azino-bis (3-ethylbenzothiazoline-6-sulfonic acid) [29]. Absorbance was measured $10 \mathrm{~min}$ after the free radical solution had been added to a sample, at wavelengths of $516 \mathrm{~nm}$ for DPPH and $734 \mathrm{~nm}$ for ABTS. The antioxidative activity of carrot juices was expressed in $\mathrm{w} \mu \mathrm{M}$ Trolox per $\mathrm{g}$ of juice.

The $\beta$-carotene content was determined according to the routine method described in the ISO standard [30]. An appropriate weighted portion of carrot juice was pounded and extracted with acetone. Then, $20 \mathrm{~mL}$ of the acetone extract and $15 \mathrm{~mL}$ of hexane were transferred to a separator and shaken to allow $\beta$-carotene to migrate to the hexane fraction. The acetone phase was transferred to the second separator and re-extracted with hexane. Next, the hydrophobic fractions from both separators were combined and their volume was measured. Then, $20 \mathrm{~mL}$ of the solution were collected from the prepared extracts, concentrated by evaporation, and injected onto a chromatographic column filled with $\mathrm{Al}_{2} \mathrm{O}_{3}$. The $\beta$-carotene fraction was collected to a measuring flask $(10 \mathrm{~mL})$ and its absorbance was measured at a wavelength of $450 \mathrm{~nm}$.

Samples for polyphenols content determination following the HPLC method were prepared according to the procedure described by Klimczak et al. [31] in own modification. $\mathrm{NaOH}\left(2 \mathrm{~mol} \cdot \mathrm{dm}^{-3}\right)$ was added $(1: 1, v / v)$ to the carrot juices prepared as described above and the sample was mixed using a Labnet vortex mixer (Edison, NJ, USA) and left in a dark place for $4 \mathrm{~h}$ (room temperature). Then, it was neutralized to $\mathrm{pH}$ from 2.1 to 2.6 with $\mathrm{HCl}\left(2 \mathrm{~mol} \cdot \mathrm{dm}^{-3}\right)$ using a $\mathrm{pH}$ meter (Metrohm, Herisau, Switzerland) and transferred quantitatively to a measuring flask with $1 \% \mathrm{~L}$-ascorbic acid dissolved in methanol. Before the chromatographic analysis, the samples were centrifuged in an MPW-260R centrifuge (Warsaw, Poland) (RCF 30,065 $\times g, 20 \mathrm{~min}, 4^{\circ} \mathrm{C}$ ) and filtered through a PTFE-L filter with pore diameter of $0.22 \mu \mathrm{m}$. Before injection onto the column, the samples were stored at $4{ }^{\circ} \mathrm{C}$.

The chromatographic analysis was carried out in the HPLC Dionex UltiMate 3000 system with DAD detector (Thermo Scientific, Germering, Germany), using a Cosmosil $5 \mathrm{C}_{18}$-MS-II column $(250 \times 4.6 \mathrm{~mm}$ ID, $5 \mu \mathrm{m})$ (Nacalai Tesque, Inc., Kyoto, Japan). Two eluents were used as the mobile phase: A, $2 \%(v / v)$ an aqueous solution of acetic acid, and B, 100\% methanol. The flow rate of the mobile phase was $1 \mathrm{~mL} \cdot \mathrm{min}^{-1}$ throughout the analysis, which lasted $50 \mathrm{~min}$ and was performed in the following

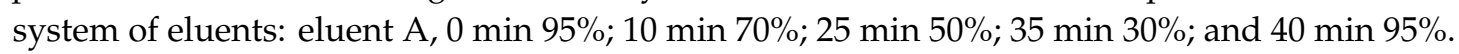

Color of the carrot juices was measured employing the transmittance method in the CIELab system [32], with the use of a Konica Minolta CM-3500d spectrophotometer (Konica Minolta Sensing, Osaka, Japan). It was measured with the reflectance method, using a Petri dish $(6 \mathrm{~cm}$ in diameter and $4 \mathrm{~cm}$ in height), at an observer angle of $10^{\circ}$ and illuminant D65. The measurement allowed determining values of the following parameters:

- $\quad \mathrm{L}^{*}$, color lightness $\left(\mathrm{L}^{*}=0\right.$ black, $\mathrm{L}^{*}=100$ white);

- $\mathrm{a}^{*}$, contribution of green $\left(\mathrm{a}^{*}<0\right)$ or red $\left(\mathrm{a}^{*}>0\right)$ color;

- $\mathrm{b}^{*}$, contribution of blue $\left(\mathrm{b}^{*}<0\right)$ or yellow $\left(\mathrm{b}^{*}>0\right)$ color.

The quantitative attribute of colorfulness is chroma $\left(\mathrm{C}^{*}\right)$ which was calculated using following equation:

$$
C^{*}=\sqrt{a^{* 2}+b^{* 2}} \text {. }
$$

Color changes between the biofortified and unfortified carrot juice samples was expressed by the total color difference $\left(\Delta \mathrm{E}_{\mathrm{ab}}^{*}\right)$. This parameter was calculated as the Euclidean distance between two points in the three-dimensional space determined by $\mathrm{L}^{*}, \mathrm{a}^{*}$, and $\mathrm{b}^{*}$ using the following formula:

$$
\Delta \mathrm{E}_{\mathrm{ab}}^{*}=\sqrt{\Delta a^{* 2}+\Delta b^{* 2}+\Delta L^{* 2}},
$$


where $\Delta \mathrm{a}^{*}, \Delta \mathrm{b}^{*}$, and $\Delta \mathrm{L}^{*}$ are the differences between the control sample carrot juice $(\mathrm{CJ})$ and biofortified carrot juice BCJ.

The analyses were performed in four repetitions. Results obtained were subjected to the statistical analysis using STATISTICA 12.0 software (Statsoft, Inc., Tulsa, OK, USA). One-way and two-way analysis of variance (ANOVA) was conducted, and the significance of differences between mean values was determined with the Duncan's test at $p<0.05$.

\section{Results and Discussion}

Selected physicochemical parameters of carrot juice depending on carrot biofortification and their varieties shown in Table 1.

Table 1. Physicochemical parameters of carrot juice depending on carrot biofortification and their varieties.

\begin{tabular}{|c|c|c|c|c|c|c|c|}
\hline & $\begin{array}{l}\text { Iodine Content } \\
\text { (mg.kg }{ }^{-1} \text { d.w.) }\end{array}$ & $\begin{array}{l}\text { Selenium Content } \\
\left(\mathrm{mg} \cdot \mathrm{kg}^{-1} \text { d.w. }\right)\end{array}$ & $\begin{array}{l}\text { Dry Matter } \\
\left(\mathrm{g} \cdot 100 \mathrm{~g}^{-1}\right)\end{array}$ & $\mathrm{pH}$ & $\begin{array}{c}\text { Total Soluble } \\
\text { Solid }\left(\mathrm{g} \cdot 100 \mathrm{~g}^{-1}\right)\end{array}$ & $\begin{array}{l}\text { Total Protein } \\
\text { (g.100 } \mathrm{g}^{-1} \text { f.w.) }\end{array}$ & $\begin{array}{c}\text { Total Sugar } \\
\text { (g.100 } \mathrm{g}^{-1} \text { f.w.) }\end{array}$ \\
\hline \multicolumn{8}{|c|}{ Biofortification $(n=12)$} \\
\hline No & $0.45 a$ & $2.10 \mathrm{a}$ & $7.00 \mathrm{~b}$ & $5.55 \mathrm{~b}$ & $7.13 b$ & $1.04 \mathrm{~b}$ & $4.99 \mathrm{~b}$ \\
\hline \multicolumn{8}{|c|}{ Variety $(n=6)$} \\
\hline Kazan $\mathrm{F}_{1}$ & $1.14 \mathrm{~b}$ & $3.31 \mathrm{a}$ & $6.61 \mathrm{~b}$ & $5.44 a$ & $6.00 \mathrm{~b}$ & $0.82 \mathrm{a}$ & $4.54 \mathrm{~b}$ \\
\hline $\begin{array}{l}\text { White } \\
\text { Satin }\end{array}$ & $0.75 a$ & $4.61 \mathrm{~b}$ & $5.15 a$ & $5.50 \mathrm{~b}$ & $4.85 \mathrm{a}$ & $0.79 a$ & $3.89 a$ \\
\hline
\end{tabular}

The same letters in the columns set no differences at $p<0.05$.

The iodine content in BCJ was depended on the carrot variety (Table 1). In each case, an increase in iodine content from 238 (for Samba $F_{1}$ ) to $448 \%$ (for Askona $F_{1}$ ) was observed in relation to the CJ (Figure 2a). CJ slightly covered the recommended daily intake of iodine (RDA $=150 \mu g$ per day), while BCJ brought significantly higher doses of this element (calculated on the consumption of $100 \mathrm{~g}$ of the product). This is particularly clear for the Askona $\mathrm{F}_{1}$ and Kazan $\mathrm{F}_{1}$ varieties (Figure 2c). In the case of CJ, the RDA coverage was 1.45-2.42\% (iodine content 2.2-3.6 $\mu \mathrm{g} / 100 \mathrm{~g}$ of fresh weight), depending on the variety, while for BCJ it was 3.77-8.15\% (iodine content 5.66-12.23 $\mu \mathrm{g} / 100 \mathrm{~g}$ fresh weight).

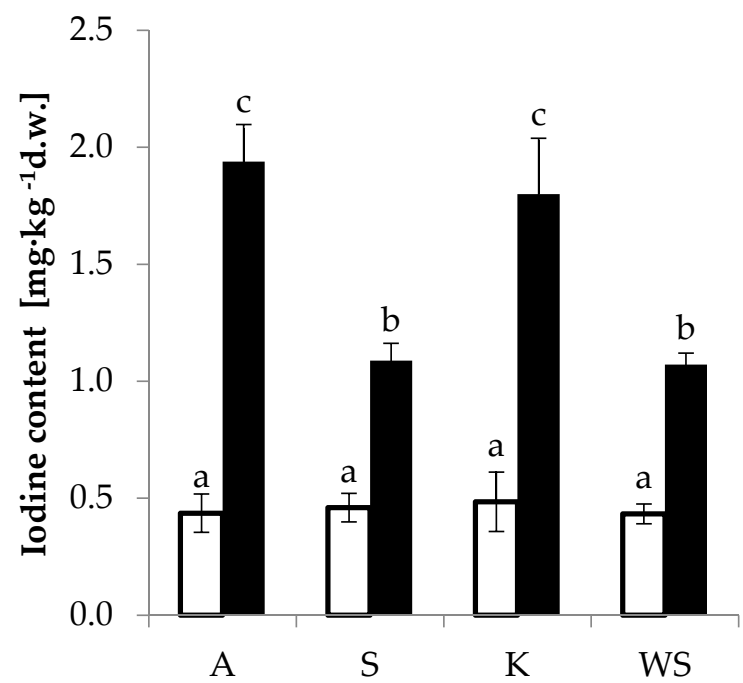

(a)

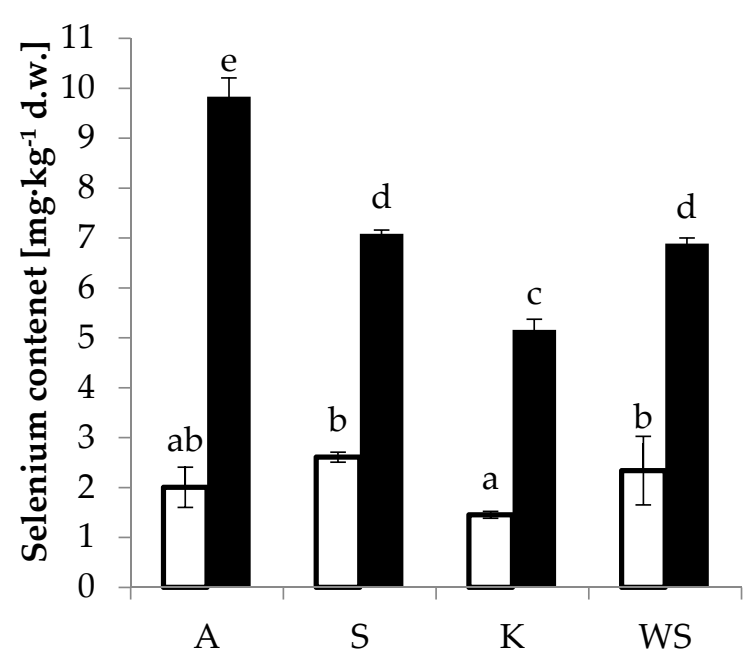

(b)

Figure 2. Cont. 


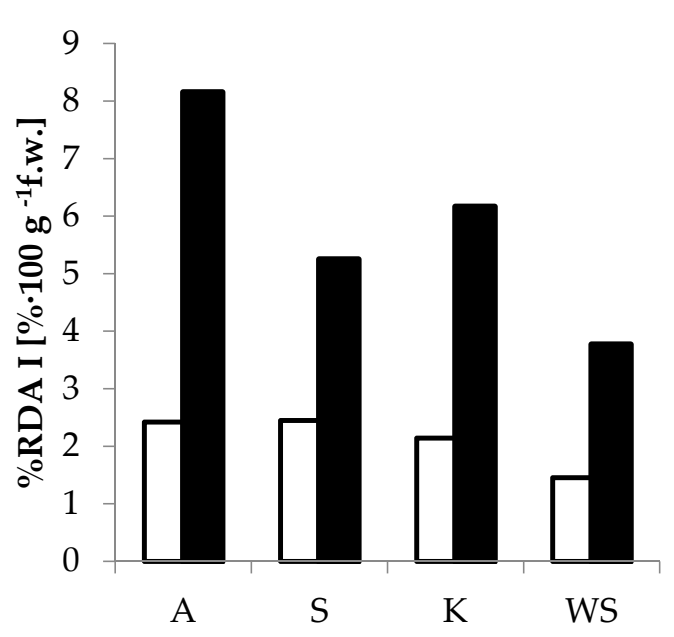

(c)

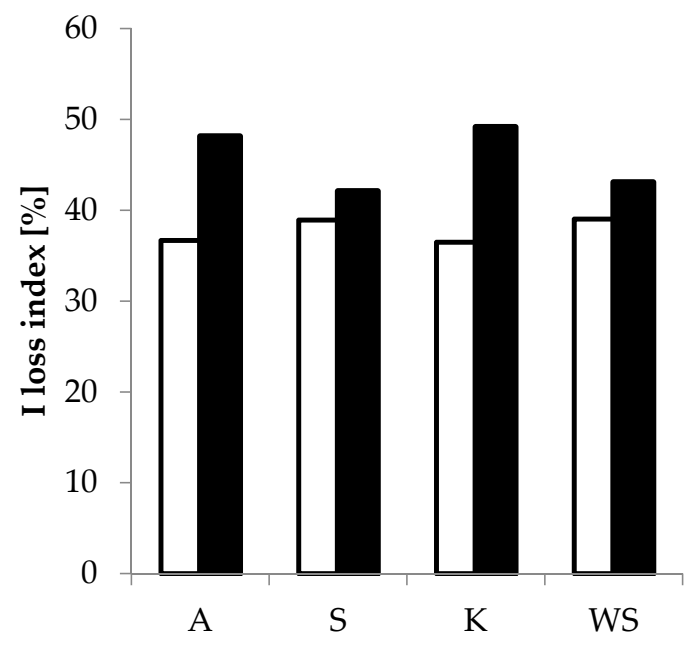

(e)

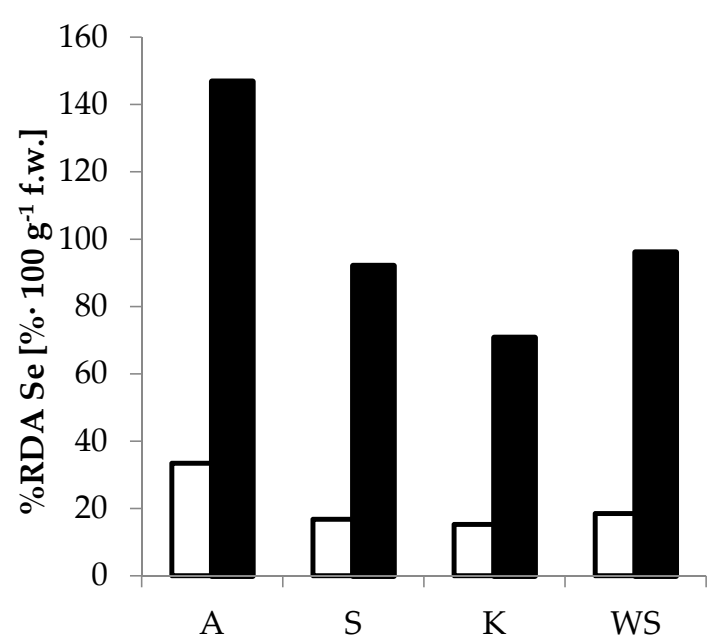

(d)

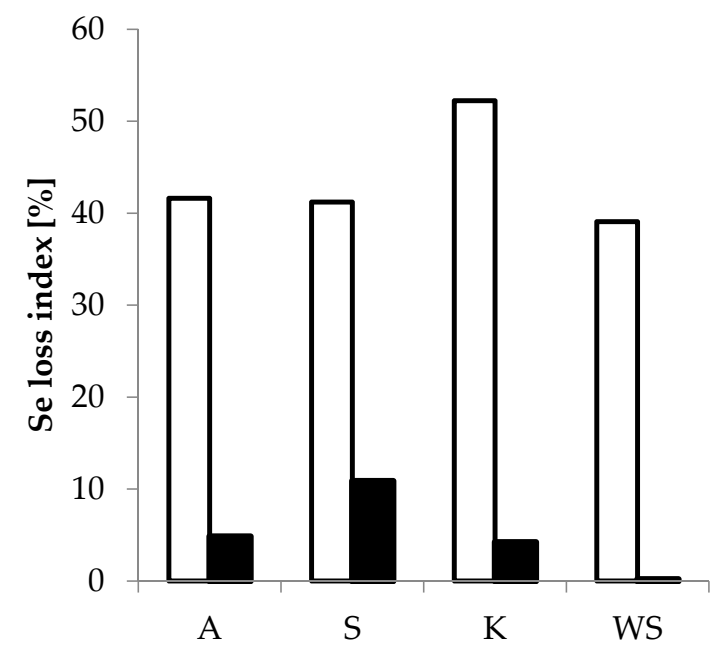

(f)

Figure 2. Iodine and selenium parameters. (a) Content of iodine; (b) Content of selenium; (c) \%RDA of iodine; (d) \%RDA of selenium; (e) Loss index of iodine; (f) Loss index of selenium. White bars, control carrot juice (CJ) and black bars, biofortified carrot juice (BCJ). Various types: A, Askona $\mathrm{F}_{1}$; S, Samba $\mathrm{F}_{1}$; $\mathrm{K}$, Kazan $\mathrm{F}_{1}$; WS, White Satin. Mean $\pm \mathrm{SE}$, the same letters set no differences at $p<0.05$.

Biofortification in selenium was more effective than enrichment in iodine despite the use of smaller doses of selenium in soil fertilization (Table 1). The selenium content in BCJ was even 4.5 times higher than in $\mathrm{CJ}$ (Figure $2 \mathrm{~b}$ ). Consumption of $100 \mathrm{~g}$ of $\mathrm{BCJ}$ from the Askona $\mathrm{F}_{1}$ variety provides a higher dose of selenium than recommended for adults (RDA $=55 \mu \mathrm{g}$ per day) (Figure 2d). In the case of CJ, the RDA coverage was, depending on the variety, 15.23-33.40\% (selenium content 8.38-18.37 $\mu \mathrm{g} / 100 \mathrm{~g}$ fresh weight), whereas for BCJ it was 70.64-146.77\% (content 38, 85-80.72 $\mu \mathrm{g} / 100 \mathrm{~g}$ fresh weight).

Taking into account the content of iodine and selenium in BCJ in the context of covering the daily requirement for these elements, the possibility of exceeding the recommended dose can also be a problem. In the case of iodine, it is unlikely because it would require an intake of at least $1200 \mathrm{~mL}$, whereas in the case of selenium, the daily recommended dose $(55 \mu \mathrm{g})$ could be exceeded with the consumption of $100 \mathrm{~mL}$ of juice. Exceeding the maximum safe dose of selenium consumption $(450 \mu \mathrm{g})$ was also possible, although it would require the consumption of more than half a liter of juice a day.

The problem of different biofortification effectiveness has been reported earlier by $[21,33]$, who suggested the need to precisely determine the doses of fertilizers. In the case of obtaining products from biofortified raw materials, it is important to obtain raw materials with an appropriate 
content of ingredients, and also to know the degree of their transfer to the finished product, which is not obvious.

It is a different matter to determine mineral losses in technological processes in relation to the raw materials. Although data on the most important macro- and micronutrients are widely available, for iodine and selenium from biofortified raw materials it is limited to a few reports. In the case of iodine, the losses of this element were similar in both the $\mathrm{CJ}$ and BCJ production processes. Depending on the variety, the I loss index was in the range of 36-39\% in the case of $\mathrm{CJ}$, whereas for BCJ it was slightly higher and was in the range of $42 \%$ and $49 \%$ (Figure 2e). A completely different tendency was observed in the case of selenium. The Se loss index in CJ was higher, from 39 to $51 \%$ in relation to the raw material, whereas in the case of BCJ the losses were only $1-10 \%$ (Figure $2 \mathrm{f}$ ). This could be due to the types of compounds these elements formed in plant materials. Iodine, in addition to mineral forms, is incorporated into compounds with salicylic acid, which is a relatively small molecule that can dissolve in water during blanching. Selenium is largely incorporated into amino acids (selenomethionine and selenocysteine) embedded in high-molecular proteins [21].

The simultaneous biofortification of carrot with iodine and selenium in the form of KI and $\mathrm{Na}_{2} \mathrm{SeO}_{4}$ during plant cultivation affects both the physical properties and the content of most of the compounds analyzed in the juices made from it. The enrichment of the raw material to a lesser extent influences the physicochemical properties of juices obtained from the white variety of carrot (Table 1).

Dry matter content of the juices ranged from 5.04 to $8.33 \mathrm{~g} \cdot 100 \mathrm{~g}^{-1}$. It was lower in BCJs made of two Askona $F_{1}$ and Samba $F_{1}$ cultivars, whereas no statistically significant differences were noted in its content between the BCJs made of the other two cultivars and the control CJ (Figure 3a). Dry matter content of CJ from orange non-biofortified carrot was similar $\left(7.99-8.72 \mathrm{~g} \cdot 100 \mathrm{~g}^{-1}\right)$ to that reported by Hallmann et al. [34] for juices made of carrots from conventional and ecological cultivations. In turn, a higher dry matter content $\left(8.99 \mathrm{~g} \cdot 100 \mathrm{~g}^{-1}\right)$ was determined by Olalude et al. [35] in one-day juices.

The biofortification increased the $\mathrm{pH}$ value of all juices, except for the juice made of $S a m b a \mathrm{~F}_{1} \mathrm{cv}$. (Figure $3 b$ ). A similar $\mathrm{pH}$ value to that obtained in our study for $\mathrm{CJ}$ from Samba $\mathrm{F}_{1} \mathrm{cv}$. was reported by Leahu et al. [36]. A thermally non-preserved juice was also analyzed by Olalude et al. [35], however its $\mathrm{pH}$ value was higher $(\mathrm{pH}=6.23)$, similar to the $\mathrm{pH}$ value $(\mathrm{pH}=6.8)$ of fresh juice produced by Martínez-Flores et al. [37]. In turn, the juice made of carrot grown in Pakistan had a slightly lower $\mathrm{pH}$ value $(\mathrm{pH}=4.99)$ [38], whereas a significantly lower $\mathrm{pH}$ value $(\mathrm{pH}=4.5)$ was demonstrated for the carrot juice from China [39]. The differences in the $\mathrm{pH}$ values reported could have been significantly affected by the composition of the soil the carrot was grown in and by its fertilization [33].

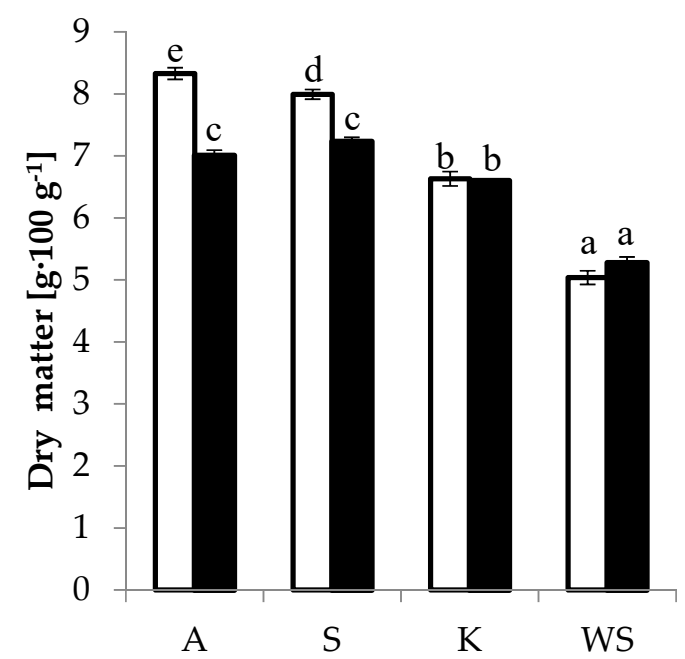

(a)

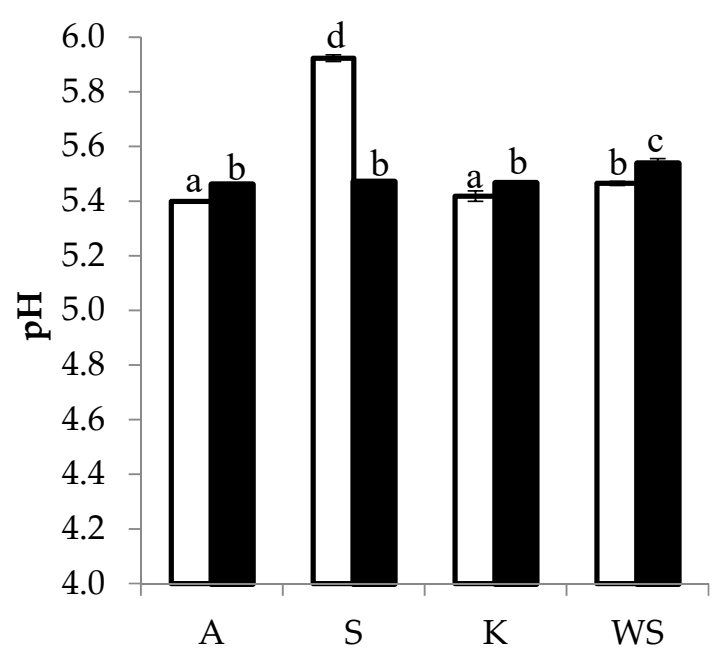

(b)

Figure 3. Cont. 


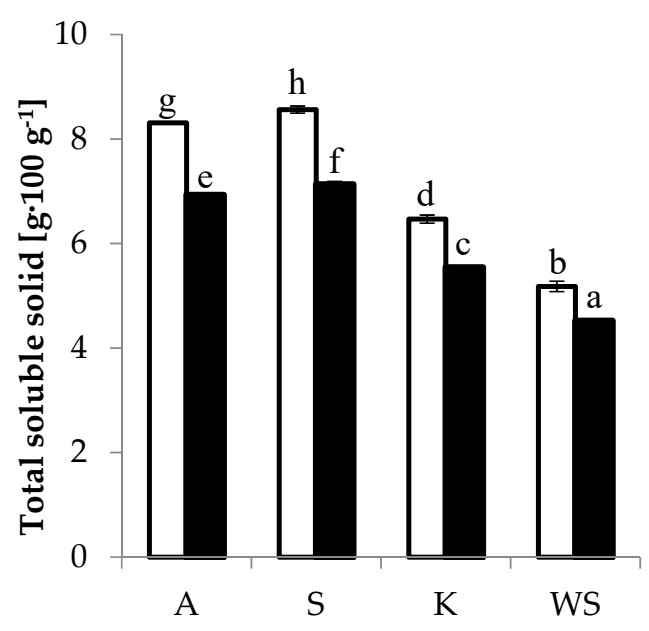

(c)

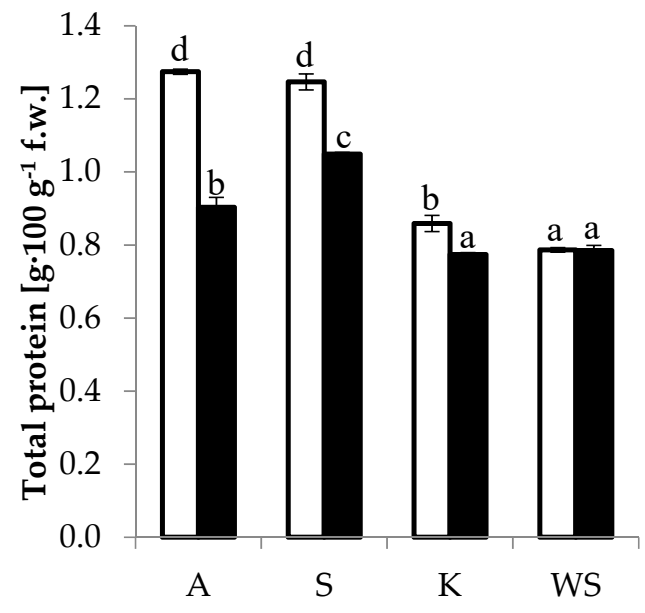

(d)

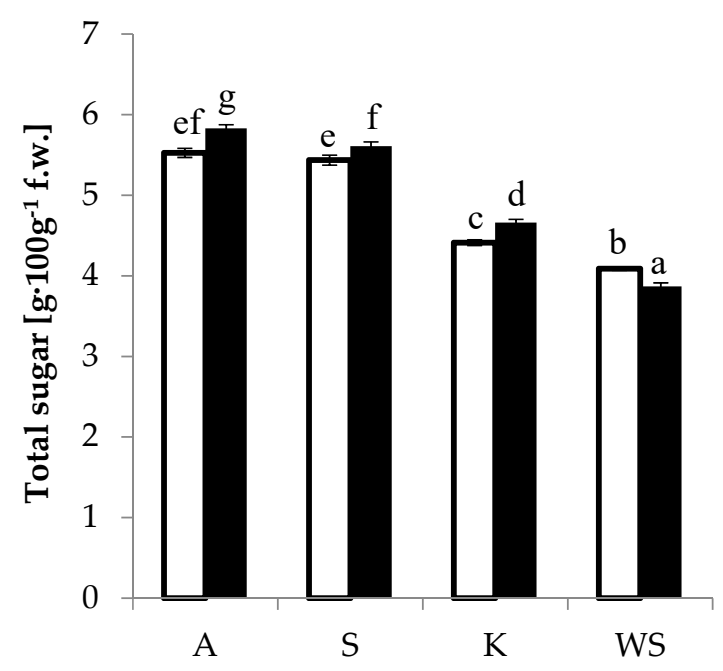

(e)

Figure 3. Selected physicochemical parameters of carrot juices. (a) Dry matter; (b) pH; (c) Total soluble solid; (d) Total protein; (e) Total sugar. White bars, CJ and black bars, BCJ. Various types: A, Askona $\mathrm{F}_{1}$; $\mathrm{S}$, Samba $\mathrm{F}_{1} ; \mathrm{K}$, Kazan $\mathrm{F}_{1}$; WS, White Satin. Mean $\pm \mathrm{SE}$, the same letters set no differences at $p<0.05$.

Total soluble solid (Figure 3c), total protein (Figure 3d), and total sugar (Figure 3e) were significantly higher in the juices from orange non-biofortified carrots, except for the total sugar content and for no differences noted in protein content noted for the juice made of White Satin cv. The TSS content of orange carrot juice produced by Leahu et al. [36] was at $7.31 \mathrm{~g} \cdot 100 \mathrm{~g}^{-1}$, which was higher than that determined in this study for the juice made of orange-root carrot Kazan $\mathrm{F}_{1} \mathrm{cv}$. and, at the same time, lower than the values obtained for juices from the other non-biofortified orange carrot cultivars. Extract content determined by Hallmann et al. [34] fitted within the range from 4.75 to $5.46 \mathrm{~g} \cdot 100 \mathrm{~g}^{-1}$ depending on cultivar and cultivation method (ecological vs. conventional). Protein content determined in carrot juice by Olalude et al. [35] reached $1 \mathrm{~g} \cdot 100 \mathrm{~g}^{-1}$, which was higher than in the carrot juice made of Kazan $\mathrm{F}_{1} \mathrm{cv}$. and lower than in the other juices made of the non-biofortified orange carrot cultivars. In turn, the content of total sugars in the juices produced in this study was lower than that reported by Olalude et al. [35], which could be due to carrot cultivar used to produce the juices (Table 1). An insignificantly higher content of sugars in the raw material from Kazan $\mathrm{F}_{1} \mathrm{cv}$. was determined in our previous article [40].

The total polyphenols content and the antioxidant activity were lower in the BCJs. The best in terms of these properties turned out to be the carrot juice made of Samba $\mathrm{F}_{1} \mathrm{cv}$. (Table 2). 
Table 2. Antioxidant activity of carrot juices depending on carrot biofortification and their varieties (results for fresh weight).

\begin{tabular}{|c|c|c|c|c|}
\hline & $\begin{array}{c}\text { ABTS } \\
\left(\mu \mathrm{mol} \mathrm{Trolox} \cdot \mathrm{g}^{-1}\right)\end{array}$ & $\begin{array}{c}\text { DPPH } \\
\left(\mu \mathrm{mol} \text { Trolox } \cdot g^{-1}\right)\end{array}$ & $\begin{array}{c}\text { Total Polyphenols } \\
\left(\mathrm{mg} \text { Catechin } \cdot 100 \mathrm{~g}^{-1}\right)\end{array}$ & $\begin{array}{l}\beta \text {-Carotene } \\
\left(\mathrm{mg} \cdot 100 \mathrm{~g}^{-1}\right)\end{array}$ \\
\hline \multicolumn{5}{|c|}{ Biofortification $(n=12)$} \\
\hline Yes & $48.7 \mathrm{a}$ & $4.0 \mathrm{a}$ & $33.6 \mathrm{a}$ & $2.04 \mathrm{a}$ \\
\hline No & $51.6 b$ & $5.1 b$ & $39.9 b$ & $2.50 \mathrm{~b}$ \\
\hline \multicolumn{5}{|c|}{ Variety $(n=6)$} \\
\hline Askona $\mathrm{F}_{1}$ & $55.4 b$ & $4.9 \mathrm{c}$ & $42.9 c$ & $3.12 \mathrm{c}$ \\
\hline Samba $F_{1}$ & $58.0 \mathrm{c}$ & $5.6 \mathrm{~d}$ & $42.4 \mathrm{c}$ & $3.39 b$ \\
\hline Kazan $\mathrm{F}_{1}$ & $43.7 \mathrm{a}$ & $4.3 b$ & $32.9 b$ & $3.57 \mathrm{~d}$ \\
\hline White Satin & $43.5 \mathrm{a}$ & $3.3 a$ & $28.7 \mathrm{a}$ & $0.00 \mathrm{a}$ \\
\hline
\end{tabular}

The same letters in the columns set no differences at $p<0.05$.

The juices prepared from the biofortified orange cultivar had a lower content of the analyzed polyphenolic compounds, except for the juice made of Samba $F_{1}$ cv. (Figure 4a). No significant differences were found in the antioxidant activity of the juice made of White Satin carrot cv., regardless of biofortification and radical applied (Figure $4 \mathrm{a}, \mathrm{b}$ ). The antioxidant activity of a fresh carrot juice against the ABTS radical demonstrated by Domaradzki et al. [41] was similar to that determined for CJ from Askona $\mathrm{F}_{1} \mathrm{cv}$. in this study. A slightly lower antioxidant activity as compared with that assayed in this study, was determined by Kidon et al. [42] for purple carrot juices. In turn, the antioxidant activity of juices against DPPH radical determined by Martínez-Flores et al. [37] was similar to that obtained in our study for $\mathrm{CJ}$ from Samba $\mathrm{F}_{1} \mathrm{cv}$. A significantly lower antioxidant activity of thermally preserved carrot juices against this radical was obtained by Quitão-Teixeira et al. [43].

The total polyphenols content in the CJ juices was higher as compared with BCJ, except for the juice made from the Askona variety, in which there was no statistically significant differences noted. The most sensitive variety of carrots for biofortification in terms of this parameter is Samba $\mathrm{F}_{1} \mathrm{cv}$. (Figure 4c). The total polyphenols content in juices produced by Martínez-Flores et al. [37] was significantly lower than that obtained in this study. A similar total content of polyphenols was determined by Smoleń et al. [40] in fresh roots of Kazan $\mathrm{F}_{1}$ carrot cv.

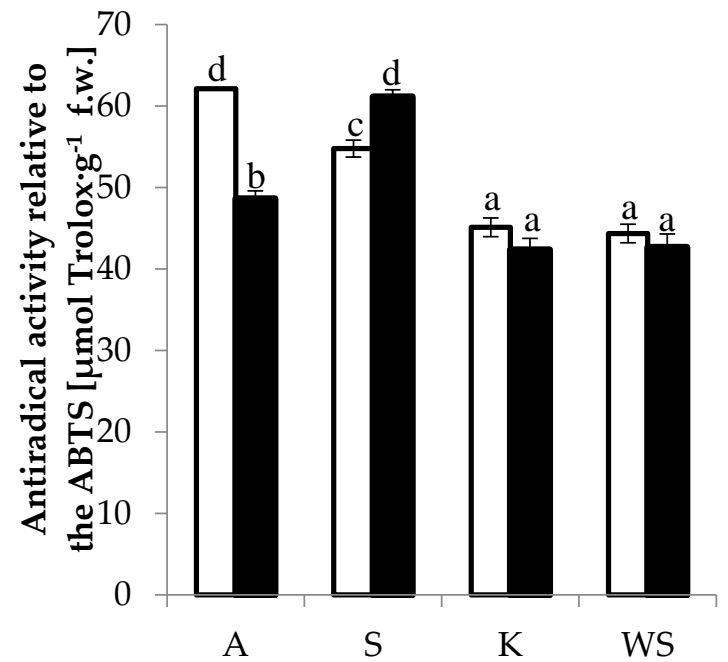

(a)

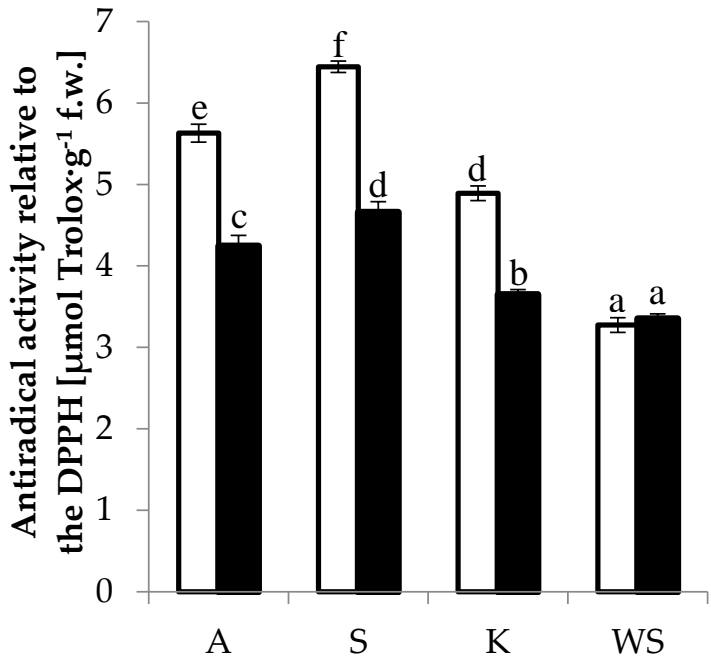

(b)

Figure 4. Cont. 


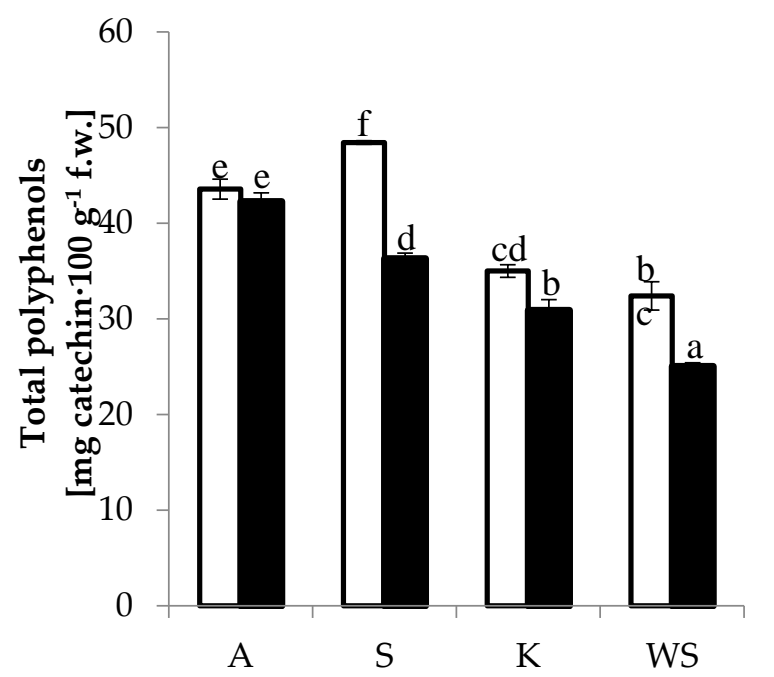

(c)

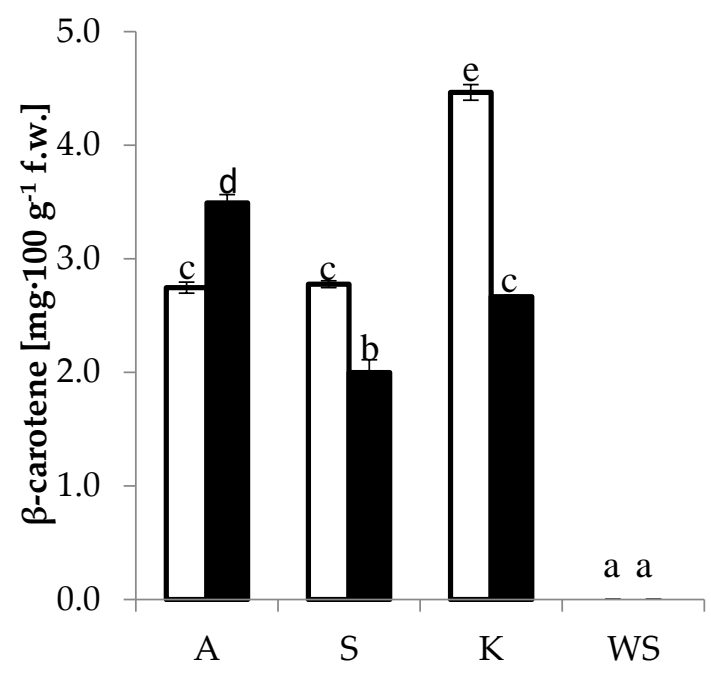

(d)

Figure 4. Antioxidant properties of carrot juices. (a) Antiradical activity relative to the ABTS; (b) Antiradical activity relative to the DPPH; (c) Total polyphenols; (d) $\beta$-carotene. White bars, CJ and black bars, BCJ. Various types: A, Askona $\mathrm{F}_{1}$; $\mathrm{S}$, Samba $\mathrm{F}_{1} ; \mathrm{K}, \mathrm{Kazan}_{\mathrm{F}}$; WS, White Satin. Mean $\pm \mathrm{SE}$, the same letters set no differences at $p<0.05$.

The BCJs also had a lower content of $\beta$-carotene than $\mathrm{CJ}$, except for these made of Askona $\mathrm{F}_{1} \mathrm{cv}$. (Figure $4 \mathrm{~d}$ ). In terms of the content of this pigment, the best cultivar for juice production turned out to be Kazan $\mathrm{F}_{1} \mathrm{cv}$. (Table 2), although it was the most strongly affected by biofortification. Similar contents of $\beta$-carotene were determined in carrot juices by other authors [44]. In a similar technological process (carrot blanching and pasteurization), they obtained $\beta$-carotene concentration at $2.8 \mathrm{mg} \cdot 100 \mathrm{~mL}^{-1}$. Its insignificantly lower concentrations, ranging from 1.58 to $1.78 \mathrm{mg} \cdot 100 \mathrm{~mL}^{-1}$ depending on carrot cultivar and juice production method, were obtained by Hallmann et al. [34]. According to Domaradzki et al. [41], one-day juices had a higher content of $\beta$-carotene $\left(8.4-8.89 \mathrm{mg} \cdot 100 \mathrm{~g}^{-1}\right)$, however they were not subjected to thermal preservation which led to its losses [45].

Polyphenols identified in carrot juices included (+) catechin, routine, as well as caffeic, ferulic, p-cumaric, and salicylic acids. Contents of caffeic, as well as ferulic and salicylic acids were higher in BCJs (Table 3).

Table 3. Selected polyphenols in carrot juices depending on carrot biofortification and their varieties (results for fresh weight).

\begin{tabular}{|c|c|c|c|c|c|c|}
\hline & $\begin{array}{l}\text { Caffeic Acid } \\
\left(\mathrm{mg} \cdot 100 \mathrm{~g}^{-1}\right)\end{array}$ & $\begin{array}{l}\text { Ferulic Acid } \\
\left(\mathrm{mg} \cdot 100 \mathrm{~g}^{-1}\right)\end{array}$ & $\begin{array}{c}\text { (+) Catechin } \\
\left(\mathrm{mg} \cdot 100 \mathrm{~g}^{-1}\right)\end{array}$ & $\begin{array}{c}\text { Routine } \\
\left(\mathrm{mg} \cdot 100 \mathrm{~g}^{-1}\right)\end{array}$ & $\begin{array}{l}\text { Salicylic Acid } \\
\left(\mathrm{mg} \cdot 100 \mathrm{~g}^{-1}\right)\end{array}$ & $\begin{array}{l}\text { p-Cumaric Acid } \\
\left(\mathrm{mg} \cdot 100 \mathrm{~g}^{-1}\right)\end{array}$ \\
\hline \multicolumn{7}{|c|}{ Biofortification $(n=12)$} \\
\hline Yes & $0.29 b$ & $0.06 b$ & $9.44 \mathrm{a}$ & $2.17 \mathrm{a}$ & $0.04 \mathrm{~b}$ & $0.022 \mathrm{a}$ \\
\hline No & $0.26 a$ & $0.05 a$ & $10.45 b$ & $2.13 a$ & $0.03 a$ & $0.022 \mathrm{a}$ \\
\hline \multicolumn{7}{|c|}{ Variety $(n=6)$} \\
\hline Askona $\mathrm{F}_{1}$ & $0.30 \mathrm{c}$ & $0.05 b$ & $9.62 c$ & $2.15 a$ & $0.03 b$ & $0.021 b$ \\
\hline Samba $F_{1}$ & $0.25 b$ & $0.06 \mathrm{c}$ & $12.32 \mathrm{~d}$ & $2.19 a$ & $0.05 c$ & $0.017 \mathrm{a}$ \\
\hline Kazan $\mathrm{F}_{1}$ & $0.47 \mathrm{~d}$ & $0.07 \mathrm{~d}$ & $8.68 \mathrm{a}$ & $2.15 \mathrm{a}$ & $0.02 \mathrm{a}$ & $0.027 \mathrm{c}$ \\
\hline White Satin & $0.09 \mathrm{a}$ & $0.04 \mathrm{a}$ & $9.17 \mathrm{~b}$ & $2.11 \mathrm{a}$ & nd & nd \\
\hline
\end{tabular}

The same letters in the columns set no differences at $p<0.05$. nd, not detected.

Juices made of the non-biofortified carrot of Kazan $\mathrm{F}_{1} \mathrm{cv}$. had higher contents of caffeic, ferulic, salicylic, and p-coumaric acids than the juices produced from the other cultivars tested. In the other $\mathrm{BCJs}$ from orange cultivars, contents of these polyphenols were higher than in the analogous CJs (Figure 5a-e). Similar dependencies were noted for the juice made from white carrot, however, 
it did not contain salicylic or p-coumaric acid. In contrast, the biofortification caused a decrease in (+)catechin content, regardless of carrot cultivar used for juice production. Likewise, study [41] detected caffeic and ferulic acids and additionally chlorogenic and 3- and 4-hydroxybenzoic acids in fresh (Karoten cv.) and thermally preserved carrot juices. In turn, according to Ma et al. [46], the prevailing polyphenol in carrot juice turned out to be caffeic acid, regardless of the juice production method (fresh, blanched, or enzymatically treated carrot). They also detected p-coumaric acid in carrot juice samples. Considering the above, it can be concluded that the composition of the polyphenolic fraction of carrot juices depends on both, cultivation conditions and juice production method.

Color is one of the most important quality attributes of food products affecting their perception by consumers. Food color predetermines consumer perceptions of freshness and expectations of flavor, smell, and nutritional value. The color parameters of the tested carrot juices depending on the biofortification of the carrot and its cultivars are presented in Table 4.

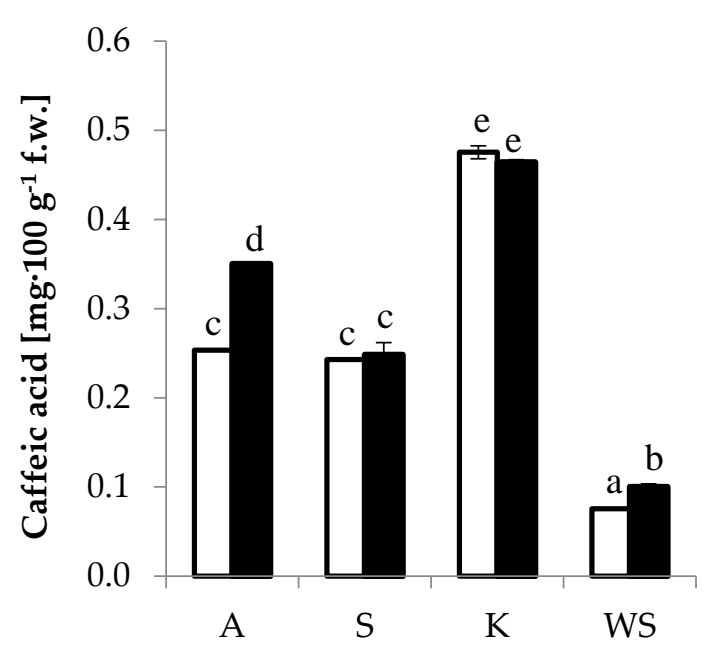

(a)

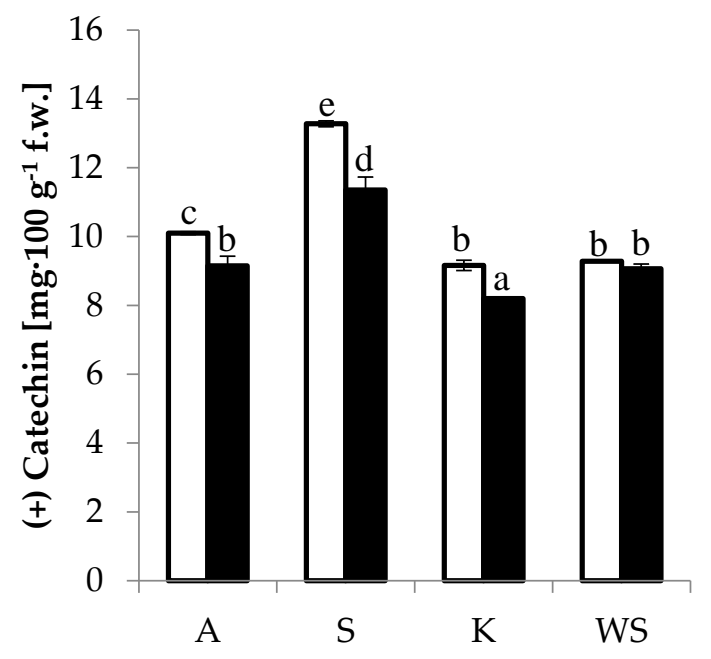

(c)

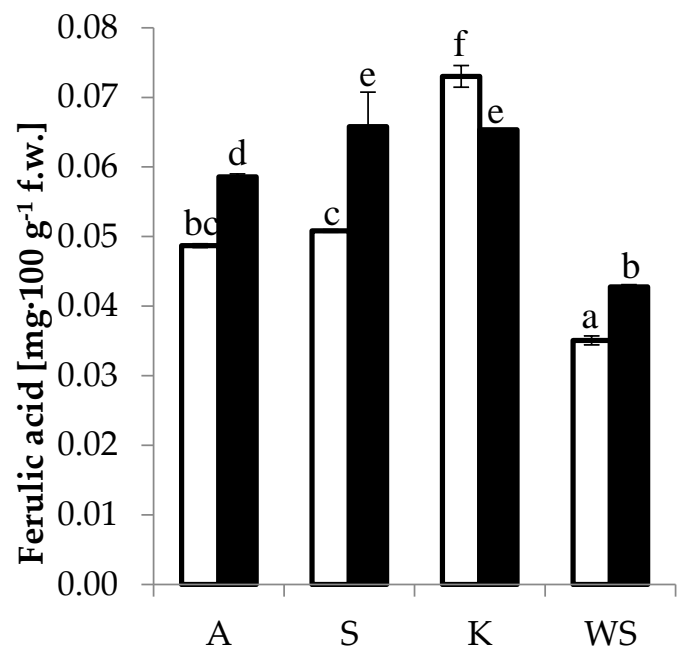

(b)

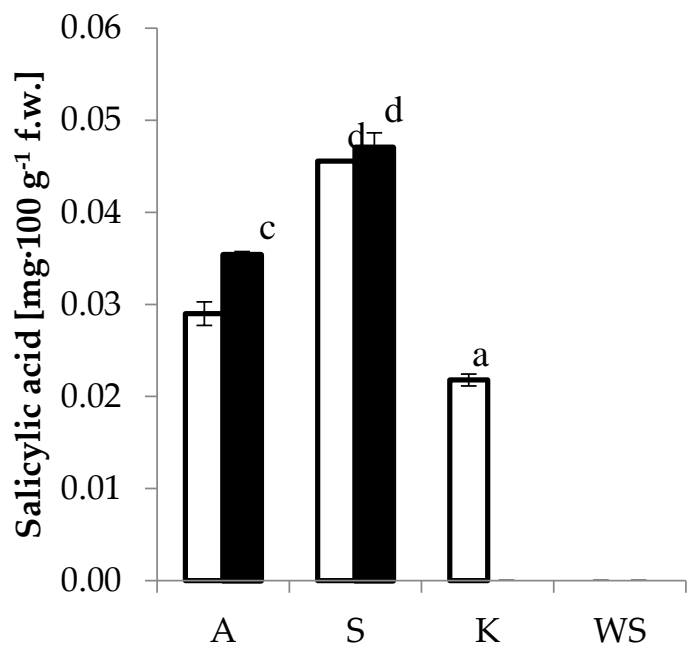

(d)

Figure 5. Cont. 


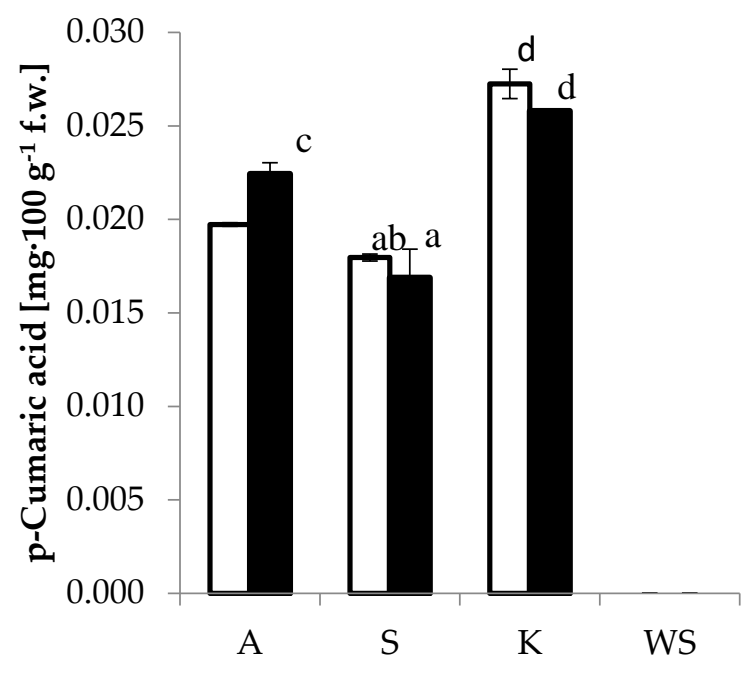

(e)

Figure 5. Selected polyphenols in carrot juices. (a) Caffeic acid; (b) Ferulic acid; (c) (+) Catechin; (d) Salicylic acid; (e) p-Cumaric acid. White bars, CJ and black bars, BCJ). Various types: A, Askona $\mathrm{F}_{1}$; $\mathrm{S}$, Samba $\mathrm{F}_{1} ; \mathrm{K}$, Kazan $\mathrm{F}_{1}$; WS, White Satin. Mean $\pm \mathrm{SE}$, the same letters set no differences at $p<0.05$.

Table 4. Color parameters of carrot juice depending on the biofortification of carrots and their varieties.

\begin{tabular}{|c|c|c|c|c|}
\hline & $\mathbf{L}^{*}$ & $a^{*}$ & $\mathbf{b}^{*}$ & $C^{*}$ \\
\hline \multicolumn{5}{|c|}{ Biofortification $(n=12)$} \\
\hline Yes & $41.4 \mathrm{~b}$ & $22.4 b$ & $42.5 b$ & $57.28 \mathrm{a}$ \\
\hline No & $41.2 \mathrm{a}$ & $22.2 \mathrm{a}$ & $41.9 \mathrm{a}$ & $56.29 a$ \\
\hline \multicolumn{5}{|c|}{ Variety $(n=6)$} \\
\hline Askona $\mathrm{F}_{1}$ & $41.7 \mathrm{~b}$ & $28.7 \mathrm{~b}$ & $50.2 c$ & $57.78 b$ \\
\hline Samba $F_{1}$ & $41.8 b$ & $28.8 b$ & $50.0 \mathrm{c}$ & $57.72 b$ \\
\hline Kazan $\mathrm{F}_{1}$ & $40.8 \mathrm{a}$ & $30.1 \mathrm{c}$ & $45.8 b$ & $54.86 \mathrm{~b}$ \\
\hline White Satin & $41.0 \mathrm{a}$ & $1.6 a$ & $22.8 \mathrm{a}$ & $22.83 a$ \\
\hline
\end{tabular}

$\mathrm{L}^{*}$ - color lightness; $\mathrm{a}^{*}$ - contribution of green or red color; $\mathrm{b}^{*}$-contribution of blue or yellow color; $\mathrm{C}^{*}$ —chroma. The same letters in the columns set no differences at $p<0.05$.

Biofortification also affected the color parameters of carrot juices. The BCJs were lighter, more red (parameter $\mathrm{a}^{*}$ ), and more yellow (parameter) (Table 4), except for the lightness and parameter $\mathrm{b}^{*}$ value noted for white carrot juice and orange Kazan $\mathrm{F}_{1} \mathrm{cv}$. juice, in the case of which the differences were not statistically significant (Figure 6a-c). One-day juices analyzed by [36] had lighter color as well as lower contribution of red and yellow colors. As a result of the pasteurization process, the color of carrot juices turned darker and the contribution of red and yellow colors increased [47]. Compared to the pasteurized juices, the juices made in this study of orange carrot cultivars were characterized by less lightness and at the same time by a higher contribution of red and yellow colors. This could have been due to the higher temperature of preservation (sterilization) and longer storage of the juices before analyses. The impact of biofortification on the color intensity of the juices of all carrot varieties is too small to be perceived by human. The chroma $C^{*}$ value for $C J$ is not statistically significant from $C^{*}$ value of BCJ juices (Figure $6 \mathrm{~d}$ ). Total color difference $\left(\Delta \mathrm{E}^{*} \mathrm{ab}\right.$ ) between $\mathrm{CJ}$ and BJC juices ranged from 0.29 (White Satin variety) to 1.97 (Samba $\mathrm{F}_{1}$ variety) CIELab units, with an average value for juices of orange carrot varieties $1.77 \pm 0.17$ CIELab units.

In carrot juice, the content of carotenoids and, in some cases anthocyanins, makes the product more colorful. Apart from changes in pigment's level, the change in yellowness can be partly due to the activity of enzymes such as polyphenol oxidases (PPOs) and peroxidase (POD), responsible 
for enzymatic browning. However, in our work, blanching carrots in the juice production process inactivates the enzymes responsible for this process.

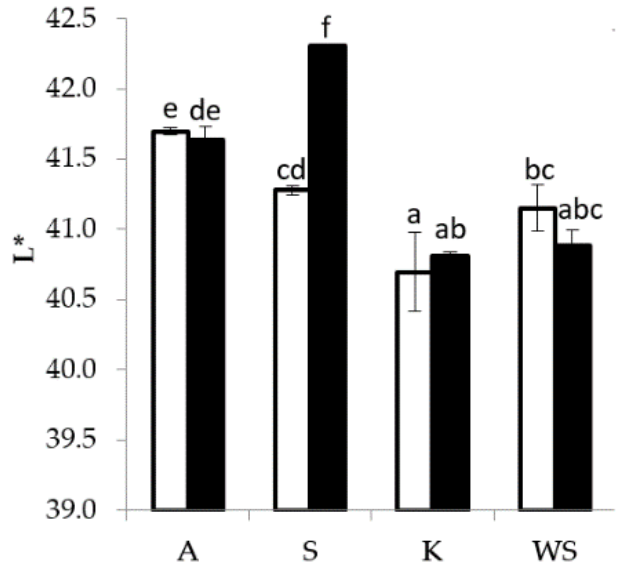

(a)

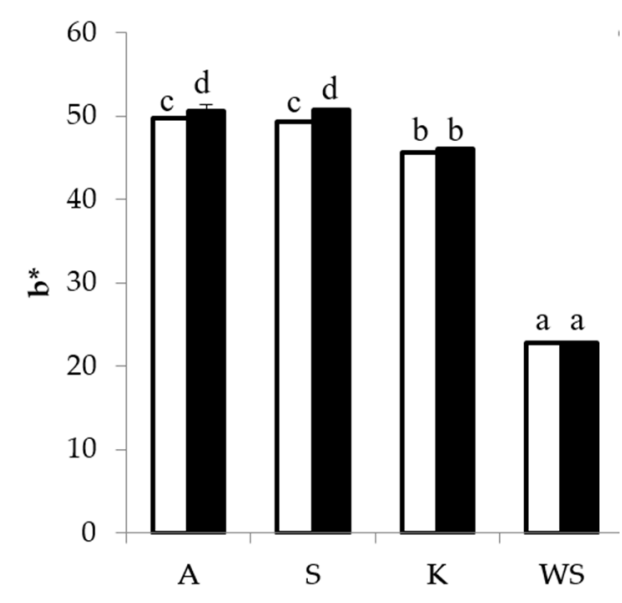

(c)

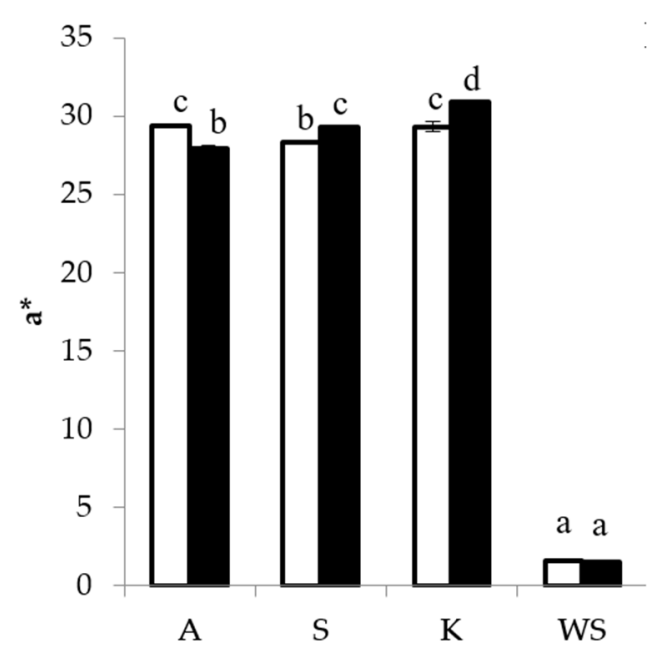

(b)

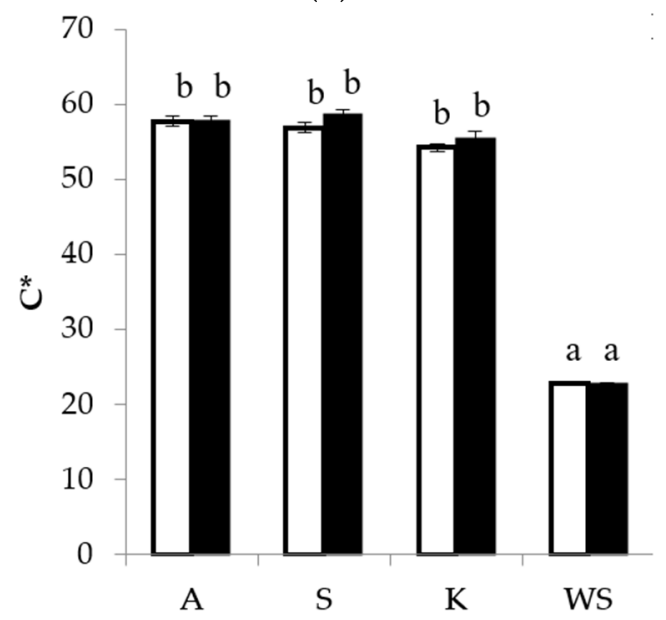

(d)

Figure 6. Selected parameters of instrumental color analysis of carrot juices. (a) Parameter $\mathrm{L}^{*}$; (b) Parameter a*; (c) Parameter b*; (d) Parameter C*. White bars, CJ and black bars, BCJ. Various types: A, Askona $\mathrm{F}_{1} ; \mathrm{S}$, Samba $\mathrm{F}_{1} ; \mathrm{K}, \mathrm{Kazan}_{1}$; WS, White Satin. Mean $\pm \mathrm{SE}$, the same letters set no differences at $p<0.05$.

\section{Conclusions}

Biofortification of carrot, used as a raw material for juice production, contributed to decreased contents of most of the analyzed compounds in BCJs, which was, however, strongly dependent on the carrot cultivar. In turn, it had a weaker effect on the quality of the juice made of White Satin carrot cultivar. Despite that, this juice revealed generally poorer properties as compared with the juices made from the orange carrot cultivars.

Carrot biofortification slightly influenced the color of juices. The greatest difference was observed for the value of $L$ parameter measured in the juice made of Samba $F_{1} \mathrm{Cv}$., which reached 1.03 units. Although this difference was statistically significant, it could not be noticed by consumers.

Considering all parameters examined, the best cultivars for the production of juices (both CJ and $\mathrm{BCJ}$ ) turned out to be Askona $\mathrm{F}_{1}$ and Samba $\mathrm{F}_{1}$. Juices produced from these carrot cultivars had higher values of the analyzed parameters than the juice made of Kazan $F_{1} \mathrm{cv}$. (except for $\beta$-carotene content). The process of carrot biofortification with iodine and selenium compounds contributed to 
a decrease in contents of dry matter, total soluble solid, and protein, as well as antioxidant activity against DPPH and total content of poliphenols in the juices produced from these cultivars, however, values of the aforementioned parameters were still higher or similar to these determined in juice made of the commercially used Kazan $\mathrm{F}_{1}$ cultivar.

Despite the aforementioned reduction in the content of some ingredients in biofortified juices, they still remain their valuable source. Their added value is definitely the increased content of iodine and selenium, which can largely cover the daily demand for these elementals.

It seems essential to minimize the effect of biofortification on the physicochemical properties of products manufactured from enriched raw materials. Therefore, it is important to continue investigations into the optimization of concentrations of elements used for raw material biofortification and to establish suitable ratios between them.

Author Contributions: Conceptualization, Ł.S., S.S., and J.S.; Formal analysis, Ł.S. and M.T.; Investigation, Ł.S. and S.S.; Methodology, Ł.S.; Project administration, Ł.S.; Resources, Ł.S., S.S., J.S., and R.B.; Software, Ł.S., M.T. and S.S.; Supervision, Ł.S.; Validation, Ł.S.; Visualization, M.T. and M.L.-S.; Writing-original draft, Ł.S., M.T., and M.L.-S.; Writing-review and editing, Ł.S. and M.L.-S. All authors have read and agreed to the published version of the manuscript.

Funding: This research received no external funding.

Acknowledgments: This research was financed by the Ministry of Science and Higher Education of the Republic of Poland.

Conflicts of Interest: The authors declare no conflict of interest.

\section{References}

1. Rayman, M.P. The importance of selenium to human health. Lancet 2000, 356, 233-241. [CrossRef]

2. Langauer-Lewowicka, H.; Pawlas, K. Selen in the environment. Environ. Med. 2016, 19, 9-16.

3. Smrkolj, P.; Stibilj, V. Determination of selenium in vegetables by hydride generation atomic fluorescence spectrometry. Anal. Chim. Acta 2004, 512, 11-17. [CrossRef]

4. Medrano-Macías, J.; Leija-Martínez, P.; González-Morales, S.; Juárez-Maldonado, A.; Benavides-Mendoza, A. Use of iodine to biofortify and promote growth and stress tolerance in crops. Front. Plant Sci. 2016, 7, 1146. [CrossRef]

5. Melse-Boonstra, A.; Jaiswal, N. Iodine deficiency in pregnancy, infancy and childhood and its consequences for brain development. Best Pr. Res. Clin. Endocrinol. Metab. 2010, 24, 29-38. [CrossRef] [PubMed]

6. Giordano, C.; Barone, I.; Marsico, S.; Bruno, R.; Bonofiglio, D.; Catalano, S.; Andò, S. Andò Endemic goiter and iodine prophylaxis in Calabria, a Region of Southern Italy: Past and Present. Nutrients 2019, 11, 2428. [CrossRef]

7. Lawson, P.G.; Daum, D.; Czauderna, R.; Meuser, H.; Härtling, J.W. Soil versus foliar iodine fertilization as a biofortification strategy for field-grown vegetables. Front. Plant Sci. 2015, 6, 450. [CrossRef]

8. Untoro, J.; Timmer, A.; Schultink, W. The challenges of iodine supplementation: A public health programme perspective. Best Pr. Res. Clin. Endocrinol. Metab. 2010, 24, 89-99. [CrossRef]

9. Smoleń, S.; Kowalska, I.; Halka, M.; Ledwożyw-Smoleń, I.; Grzanka, M.; Skoczylas, Ł.; Czernicka, M.; Pitala, J. Selected aspects of iodate and iodosalicylate metabolism in lettuce including the activity of vanadium dependent haloperoxidases as affected by exogenous vanadium. Agronomy 2019, 10, 1. [CrossRef]

10. Koronowicz, A.A.; Kopeć, A.; Master, A.; Smoleń, S.; Piatkowska, E.; Bieżanowska-Kopeć, R.; Ledwożyw-Smoleń, I.; Skoczylas, Ł.; Rakoczy, R.; Leszczyńska, T.; et al. Transcriptome profiling of Caco-2 cancer cell line following treatment with extracts from iodine-biofortified Lettuce (Lactuca sativa L.). PLoS ONE 2016, 11, e0147336. [CrossRef]

11. Piątkowska, E.; Kopeć, A.; Bieżanowska-Kopeć, R.; Pysz, M.; Kapusta-Duch, J.; Koronowicz, A.A.; Smoleń, S.; Skoczylas, Ł.; Ledwożyw-Smoleń, I.; Rakoczy, R.; et al. The impact of carrot enriched in iodine through soil fertilization on iodine concentration and selected biochemical parameters in wistar rats. PLoS ONE 2016, 11, e0152680. [CrossRef] [PubMed]

12. Bouis, H.; Hotz, C.; McClafferty, B.; Meenakshi, J.V.; Pfeiffer, W.H. Biofortification: A new tool to reduce micronutrient malnutrition. Food Nutr. Bull. 2011, 32, S31-S40. [CrossRef] [PubMed] 
13. Lyons, G. Biofortification of cereals with foliar selenium and iodine could reduce hypothyroidism. Front. Plant Sci. 2018, 9, 1-8. [CrossRef] [PubMed]

14. Smoleń, S.; Kowalska, I.; Sady, W. Assessment of biofortification with iodine and selenium of lettuce cultivated in the NFT hydroponic system. Sci. Hortic. 2014, 166, 9-16. [CrossRef]

15. Jerše, A.; Maršić, N.K.; Kroflič, A.; Germ, M.; Sircelj, H.; Stibilj, V. Is foliar enrichment of pea plants with iodine and selenium appropriate for production of functional food? Food Chem. 2018, 267, 368-375. [CrossRef]

16. Gonnella, M.; Renna, M.; D’Imperio, M.; Santamaria, P.; Serio, F. Iodine biofortification of four brassica genotypes is effective already at low rates of potassium iodate. Nutrients 2019, 11, 451. [CrossRef]

17. Kapusta-Duch, J.; Bieżanowska-Kopeć, R.; Smoleń, S.; Pysz, M.; Kopeć, A.; Piatkowska, E.; Rakoczy, R.; Koronowicz, A.; Skoczylas, Ł.; Leszczyńska, T. The effect of preliminary processing and different methods of cooking on the iodine content and selected antioxidative properties of carrot (Daucus carota L.) biofortified with (potassium) iodine. Folia Hortic. 2017, 29, 11-24. [CrossRef]

18. Cerretani, L.; Comandini, P.; Fumanelli, D.; Scazzina, F.; Chiavaro, E. Evaluation of iodine content and stability in recipes prepared with biofortified potatoes. Int. J. Food Sci. Nutr. 2014, 65, 797-802. [CrossRef]

19. Sharma, K.D.; Karki, S.; Thakur, N.S.; Attri, S. Chemical composition, functional properties and processing of carrot-A review. J. Food Sci. Technol. 2011, 49, 22-32. [CrossRef]

20. Dias, J.C.d.S. Nutritional and health benefits of carrots and their seed extracts. Food Nutr. Sci. 2014, 5, 2147-2156. [CrossRef]

21. Smoleń, S.; Baranski, R.; Ledwożyw-Smoleń, I.; Skoczylas, Ł.; Sady, W. Combined biofortification of carrot with iodine and selenium. Food Chem. 2019, 300, 125202. [CrossRef] [PubMed]

22. PN-EN 15111. Foodstuffs-Determination of Trace Elements-Determination of Iodine by ICP-MS (Inductively Coupled Plasma Mass Spectrometry); Comite Europeen de Normalisation: Warszawa, Poland, 2008.

23. Smoleń, S.; Kowalska, I.; Skoczylas, Ł.; Liszka-Skoczylas, M.; Grzanka, M.; Halka, M.; Sady, W. The effect of salicylic acid on biofortification with iodine and selenium and the quality of potato cultivated in the NFT system. Sci. Hortic. 2018, 240, 530-543. [CrossRef]

24. AOAC. Official Methods of Analysis. Association of Official Analytical Chemists, 16th ed.; Association of Official Analytical Chemists International: Washington, DC, USA, 1995.

25. AOAC. Official Methods of Analysis. Association of Official Analytical Chemists, 14th ed.; Association of Official Analytical Chemists International: Arlington, VA, USA, 1984.

26. Leyva, A.; Quintana, A.; Sánchez, M.; Rodríguez, E.N.; Cremata, J.; Sánchez, J.C. Rapid and sensitive anthrone-sulfuric acid assay in microplate format to quantify carbohydrate in biopharmaceutical products: Method development and validation. Biologicals 2008, 36, 134-141. [CrossRef] [PubMed]

27. Singleton, V.L.; Orthofer, R.; Lamuela-Raventós, R.M. Analysis of total phenols and other oxidation substrates and antioxidants by means of folin-ciocalteu reagent. Methods 1999, 299, 152-178. [CrossRef]

28. Brand-Williams, W.; Cuvelier, M.; Berset, C. Use of a free radical method to evaluate antioxidant activity. LWT 1995, 28, 25-30. [CrossRef]

29. Re, R.; Pellegrini, N.; Proteggente, A.; Pannala, A.; Yang, M.; Rice-Evans, C. Antioxidant activity applying an improved ABTS radical cation decolorization assay. Free. Radic. Boil. Med. 1999, 26, 1231-1237. [CrossRef]

30. ISO 6558-2:1992. Fruits, Vegetables and Derived Products-Determination of Carotene Content-Part 2: Routine Methods. Available online: https://www.iso.org/cms/render/live/en/sites/isoorg/contents/data/ standard/01/29/12960.html (accessed on 21 February 2020).

31. Klimczak, I.; Małecka, M.; Szlachta, M.; Gliszczyńska-Świgło, A. Effect of storage on the content of polyphenols, vitamin $C$ and the antioxidant activity of orange juices. J. Food Compos. Anal. 2007, 20, 313-322. [CrossRef]

32. Wrolstad, R.E.; Smith, D.E. Color Analysis; Springer: Cham, Switzerland, 2017; pp. 545-555.

33. Smoleń, S.; Skoczylas, Ł.; Ledwożyw-Smoleń, I.; Rakoczy, R.; Kopeć, A.; Piątkowska, E.; Bieżanowska-Kopeć, R.; Koronowicz, A.; Kapusta-Duch, J. Biofortification of Carrot (Daucus carota L.) with iodine and selenium in a field experiment. Front. Plant Sci. 2016, 7, 1-17. [CrossRef]

34. Hallmann, E.; Sikora, M.; Rembiałkowska, E.; Marszałek, K.; Lipowski, J. The influence of pasteurization process on nutritive value of carrot juices from organic and conventional production. J. Agric. Eng. 2011, 56, 133-137.

35. Olalude, C.B.; Oyedeji, F.O.; Adegboyega, A.M. Physico-chemical analysis of Daucus Carota (Carrot) juice for possible industrial applications. IOSR J. Appl. Chem 2015, 8, 110-113. 
36. Leahu, A.; Damian, C.; Carpiuc, N.; Oroian, M.; Avramiuc, M. Change in colour and physicochemical quality of carrot juice mixed with other fruits. J. Agroaliment. Process. Technol. 2013, 19, 241-246.

37. Martínez, H.E.; Garnica-Romo, M.; Bermúdez-Aguirre, D.; Pokhrel, P.R.; Barbosa-Cánovas, G.V. Physico-chemical parameters, bioactive compounds and microbial quality of thermo-sonicated carrot juice during storage. Food Chem. 2015, 172, 650-656. [CrossRef] [PubMed]

38. Shakeel, A.; Saeed, M.; Aslam, H.K.W.; Naheed, N.; Shoaib, M.; Sakandar, H.A.; Raza, M.S. Optimization of colour and cloud stability of carrot juice by using hydrocolloids and antioxidant. J. Glob. Innov. Agric. Soc. Sci. 2015, 3, 84-89. [CrossRef]

39. Zhang, Y.; Liu, X.; Wang, Y.; Zhao, F.; Sun, Z.; Liao, X. Quality comparison of carrot juices processed by high-pressure processing and high-temperature short-time processing. Innov. Food Sci. Emerg. Technol. 2016, 33, 135-144. [CrossRef]

40. Smoleń, S.; Sady, W.; Ledwożyw-Smoleń, I.; Strzetelski, P.; Liszka-Skoczylas, M.; Rożek, S. Quality of fresh and stored carrots depending on iodine and nitrogen fertilization. Food Chem. 2014, 159, 316-322. [CrossRef] [PubMed]

41. Domaradzki, P.; Malik, A.; Zdyb, J. The content of polyphenolic compounds and antioxidant activities of carrot juices. Brom. Toxicol. Chem. 2013, 46, 40-47.

42. Kidoń, M.; Czapski, J. Evaluation of changes on the contents of bioactive compounds and antioxidant capacity of purple carrot juices during storage. Brom. Toxicol. Chem. 2009, 42, 848-853.

43. Quitão-Teixeira, L.J.; Odriozola-Serrano, I.; Soliva-Fortuny, R.; Mota-Ramos, A.; Martín-Belloso, O. Comparative study on antioxidant properties of carrot juice stabilised by high-intensity pulsed electric fields or heat treatments. J. Sci. Food Agric. 2009, 89, 2636-2642. [CrossRef]

44. Yu, L.J.; Rupasinghe, H.V. Effect of acidification on quality and shelf-life of carrot juice. Can. J. Plant Sci. 2012, 92, 1113-1120. [CrossRef]

45. Cinquanta, L.; Albanese, D.; Cuccurullo, G.; Di Matteo, M. Effect on orange juice of batch pasteurization in an improved pilot-scale microwave oven. J. Food Sci. 2010, 75, E46-E50. [CrossRef]

46. Ma, T.; Tian, C.; Luo, J.; Zhou, R.; Sun, X.; Ma, J. Influence of technical processing units on polyphenols and antioxidant capacity of carrot (Daucus carrot L.) juice. Food Chem. 2013, 141, 1637-1644. [CrossRef]

47. Khalil, A.W.; Ali, J.; Paracha, G.M.; Iman, S.; Hassan, S. Effect of heat treatments on some quality parameters of carrot (Dascus Carota L.) juice. World J. Dairy Food Sci. 2015, 10, 55-59.

(C) 2020 by the authors. Licensee MDPI, Basel, Switzerland. This article is an open access article distributed under the terms and conditions of the Creative Commons Attribution (CC BY) license (http://creativecommons.org/licenses/by/4.0/). 